\title{
TITLE:
}

\section{The African Great Ape Bushmeat Crisis}

\section{AUTHOR(S):}

Rose, Anthony L.

\section{CITATION:}

Rose, Anthony L.. The African Great Ape Bushmeat Crisis. Pan Africa News 1996, 3(2): 1-6

\section{ISSUE DATE:}

1996-12

URL:

http://hdl.handle.net/2433/143344

\section{RIGHT:}

Copyright (C) Pan Africa News. 


\section{The African Great Ape Bushmeat Crisis}

Anthony L. Rose, Ph.D.

Executive Director / The Biosynergy Institute

The people of Africa's equatorial forest region have been hunting and eating forest animals for millennia. A mix of hunting techniques and taboos have evolved, with indigenous beliefs and methods being overlaid and infilled by the ritual and technology of myriad nomads, missionaries, conquerors, and colonials. As a result, the animals eaten by humans in one forest may be quite different from those people eat in the next. To add to the complexity, millions of people have moved from forest and rural communities into tówns and cities, bringing with them countless eating styles and food preferences. For many there is nothing better than pangolin or bush pig. Others prefer primates.

Understandably, many of us who study and conserve primates are uncomfortable seeing them on the menu. This discomfort may be ego-centric, born of our own personal eating taboos or our concern that animals at our field sites may be killed before we've finished our research. It may be anthropocentric-- a manifestation of our reluctance to eat anything so human-like as a gorilla or baboon. Or it 
may come from a bio-centric concern for individuals and species that are on the verge of extinction, high on the food chain, or demonstrably sentient and subject to suffering. To reach the broadest audience we will focus on animals that are covered by all these factors - the great apes.

It has long been known that many people in west and central Africa eat monkeys and apes $(11,12)$. Not only is it part of the lore, it is part of the economy. Bushmeat is big business, accounting for a significant portion of the animal protein consumed in the region. An in depth year long study by Steele (23) in Gabon found over 50\% of the meat sold in markets was wild game. Gross sales were estimated at 50 million dollars. Primates account for $20 \%$ of that commerce. Ammann (1) has observed gorillas and chimpanzees fresh from the hunt being butchered, smoked, and sold in almost every country in the region, from Korup to Kinshasa. Ammann and Pearce (4) report "the hunters in the Kika, Moloundou and Mabale triangle in Cameroon estimate that around 25 guns are active on any given day and that successful gorilla hunts take place on about $10 \%$ of outings. This would result in an estimated kill of up to 800 gorillas a year." If 3,000 gorillas live in that 10,000 sq. $\mathrm{km}$ area, the off-take is not sustainable. These same hunters say they bring out chimpanzee too, half as many as gorillas in this location -- up to 400 .

Sustainable or not; the slaughter of 1,200 great apes in one territory in one year is of serious concern. One must ask how many other locations there are with similar hunting scenarios. Are the gorilla ribs and chimp arms sold for meat in the markets of Congo, CAR and Gabon all coming from south-east Cameroon? Not likely. Ammann and WSPA's investigations suggest these are each the tips of separate icebergs, and that for every ape carcass on display in the markets of Ouesso, Bangui, and Libreville there are five or more sold privately, poached from nearby forests. A recent study by Hennessey (9) reports that $13 \%$ of the bushmeat sold in Ouesso is trucked in from Cameroon. The rest is local, with $64 \%$ of the meat coming "from an $80 \mathrm{~km}$ road traveling southwest to a village called Liouesso" where a hunter who specializes in gorilla is responsible for most of the 1.6 gorilla carcasses sold each week in the marketplace. That is over 80 gorillas per year in one city. Hennessey projects that 50 forest elephants are killed annually for meat and ivory in this same study, but only 19 chimpanzees. This finding counters Eliot's (6) report that "in Congo alone poachers claim up to 3000 chimps and 600 gorillas a year -leaving hundreds of orphans."

There are at least two possible explanations. It may be that there are more gorillas than chimps in the Ouesso area, with the reverse being true for the whole of Congo. The revised Status Survey on African Primates (14) reports "perhaps 80,000 central chimpanzees ( $P$. t. troglodytes) found chiefly in Gabon and Congo", as compared to "over 110,000 G. g. gorilla spread across Cameroon, CAR, Congo, Equatorial Guinea, Gabon, and ... Southeast Nigeria" (see 8).
An alternate explanation is that Eliot's information may be an extrapolation from the count of orphans. Both Ammann (1) and Redmond (15) report that among the orphans of the bushmeat trade, the chimps have a relatively high survival rate, while gorilla infants tend to die in the first 2 or 3 weeks of capture. Thus the number of orphans that reach the city is a poor indicator of the number of adult apes killed.

Historic reports from poachers indicate preference for hunting chimpanzees -- hit one chimp and the others flee, while gorillas stand their ground or even attack the hunters. The introduction of the chevrotine cartridge that fells gorilla in a single shot has changed that. Bushmeat hunters supplied with this cartridge are successful in downing a silverback and chasing off the rest of the group. A hunter interviewed extensively in Cameroon reports taking a gorilla a week during his three years operating in the forest (1). He also said that gorilla meat is more easily smoked and passed off as buffalo, which makes it easier to sell openly in some areas. As public awareness of the law against hunting and selling ape meat grows, the commerce goes underground. These factors complicate census of the great ape bush meat trade.

While it is tempting to hypothesize the number of great apes killed as bushmeat in the whole of west and central Africa, there is not enough data to do so. I have tried to explain the scope of the problem in relative terms. Many more gorillas are eaten each year than now live in the Virunga Mountains, more chimps than inhabit Gombe stream and Mahale, more apes altogether than live in the zoos and laboratories of North America, far more than are cared for in the great ape orphanages and sanctuaries on any continent -more than we'll ever know. If we are concerned about those respected and relatively well protected apes, we should double our concern for the tens of thousands that are seen only as meat.

What makes this a crisis is not only the numbers, but the way they develop. The severity of the situations reported by Wilkie (25) in Congo and Fa (7) in Equatorial Guinea have been found to hold across the region by Ammann (2). Juste (10) crystallizes the essence of the crisis: "With the advent of modern firearms, and improved communications and transport, subsistence hunting has given way to anarchic exploitation of wildlife to supply the rapidly growing cities with game." The key word here is anarchic. Absent an effective political authority, having no cohesive principle, common standard or purpose, the bushmeat trade has exploded into a rush for personal profit not unlike the goldrush that transformed the western portion of the United States in the last century. One timber company executive described it rhetorically: "if you found this hundred franc note lying on the ground, would you pick it up?" Bushmeat is like found money. Trouble is, once it's gone, there is no mint to produce more.

We know that hungry humans can hunt and eat species to oblivion. That is already happening along each new roadway into the African forests. It is the logging 
companies that provide the physical and social infrastructure for this anarchic exploitation. They put in the roads, lorries, and build the logging camps, bring in the workers, their families, transport the hunters, sometimes even provide guns and bullets. Anarchy comes from what they don't provide -domestic foods, wildlife conservation education, controlled hunting licenses and seasons, guards and game wardens, an ethos of respect for natural and cultural heritage, representative government, or law and order. This kind of free-wheeling frontier culture was a root cause of wildlife destruction in North America (22). Recent studies by Oates $(13,14)$ suggest it may be the same in Africa as well, as hunting becomes a huge un-policed commercial enterprise.

At a bush meat market in Yaounde, a baby chimpanzee was stored in a freezer(Photo by Karl Ammann)

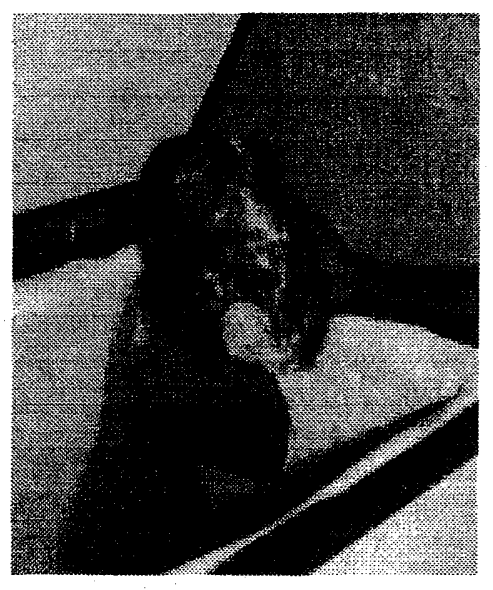

\section{Bushmeat Crisis: 'Corrective Efforts}

There are alternatives. A growing awareness of the crisis has evoked corrective efforts. The balance of this paper will outline some of those efforts, and suggest further action. What follows is a short list of events that we believe are signs of progress. We hope this will stimulate others to write and publish the many accomplishments of which we are unaware.

Public Campaign. Karl Ammann began in 1989 to document the expansion of the bushmeat trade in Zaire (3). The same year International Primate Protection League (IPPL) contracted Ian Redmond (15) to investigate primate trade in Congo. Ammann continued his investigation in dozens of visits across the region through 1994 when the World Society for the Protection of Animals (WSPA) teamed up with him to expand the study and launch a public campaign that has achieved global recognition of the crisis (4).

Political Resolve. In March, 1996, the Joint Congress of European Union and African-Pacific-Caribbean nations met in Namibia, reviewed Ammanin and WSPA's findings, recognized the terrible scope of the great ape bushmeat crisis and resolved to sanction the timber industry and involved governments, demanding they take action to stop the killing of protected and endangered animals for commercial meat trade.

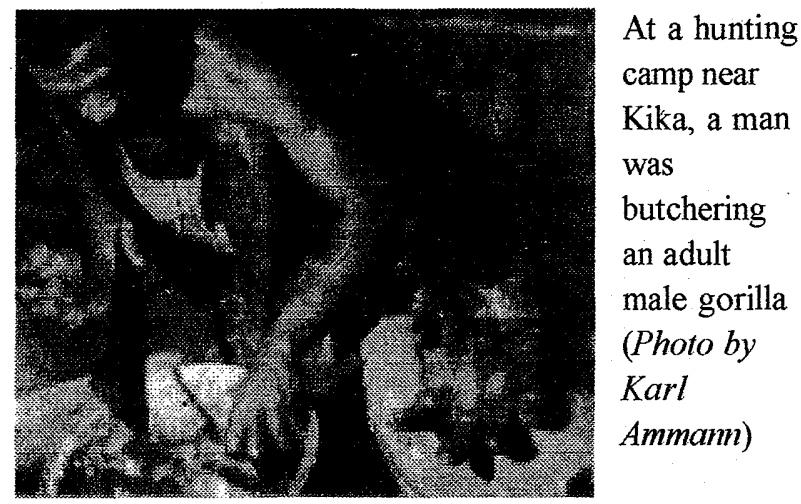

African Response. In April 1996 the Cameroon Ministry of Environment and Forests (MINEF) held a conference on "The Impact of Forest Exploitation on Wildlife". The meeting, referred to as The Bushmeat Conference, was sponsored jointly by MINEF and the World Society for the Protection of Animals (WSPA) and was organized by the Yaounde based NGO Enviro-Protect (5). The conference took place in Bertoua, capital of Cameroon's Eastern Province where logging roads have opened up thousands of square miles of new forests to exploitation. The $50+$ delegates to the conference and over two dozen observers confirmed the bushmeat crisis was linked directly to the timber industry (2) and concluded that continued bushmeat hunting in general and great ape slaughter in particular is unsustainable at present levels, and would become an irreversible wildlife disaster if permitted to continue uncontrolled. Cameroon's Director of Wildlife and Protected areas, B.Yadji (26) called for "a new dynamic of conservation and development with the people and wildlife in partnership" and proposed a national policy placing $30 \%$ of remaining forests in protected status. Agreement was unanimous that these worthy goals could be reached with international support. The conferees asked and this author agreed (17) to seek support in the United States to confront the bushmeat crisis and conserve their natural heritage.

USA Reaction. In May, 1996, The Bushmeat Project was founded as a department of The Biosynergy Institute in Los Angeles and we began developing a bushmeat data base, writing papers and proposals, recruiting support and building awareness about the bushmeat crisis, especially as it pertains to the African great apes. In June, Ammann (1) spoke to the World Animal Congress in Washington, DC and we met with ethicist Peter Singer of the Great Ape Project, Jane Goodall, and scores of other animal advocates who agreed to stimulate public and professional support to confront the great ape bushmeat crisis.

In August, 1996 we reported on the bushmeat crisis to the ASP Conservation Committee (18) and conducted a Bushmeat Crisis Workshop (19) at the IPS/ASP Congress in Madison, Wisconsin. Over 30 primatologists with field experience in west and central Africa confirmed that hunting of great apes and other primates for meat is the most serious 
threat to their survival and that the crisis extends across the forest belt from Equatorial Guinea to Zaire. Dr. Russell Mittermeier invited me to present a synopsis of the bushmeat crisis report at the IUCN Roundtable Discussion (20), where conferees again confirmed this to be a most critical issue that should be included in the primate conservation action agenda.

EU Reaction. Television and print media have carried this story in Europe and in Africa (27). Public desire for corrective action is high. In August the European Forestry Stewardship Council reviewed the recommendations of the Cameroon Bushmeat Conference and decided to make bushmeat control part of the timber certification process. They asked Ammann and WSPA to collaborate with the NGO Société General de Surveillance (SGS) in monitoring the audits that assess logging operations, to help assure compliance with protected species laws. In September Ammann met with SGS auditors in Brazzaville to formulate bushmeat monitoring methods and procedures based on the Bertoua Conference resolutions. This important step promises to put some teeth in the sanctions -- timber companies that don't meet bushmeat standards will loose their certification and their standing as ecologically sound operators.

These are a sample of the actions and reactions that have grown out of one public campaign. Dozens of individuals and organizations have contacted us describing ongoing and proposed events and efforts that impact the bushmeat crisis. In forthcoming reviews we will describe more of these important projects.

\section{Bushmeat Crisis: Ideas For Further Action}

As part of a larger proposal still in working draft form (21), we have identified five major elements that must be included in any programme that intends to transform the bushmeat commerce into a controlled and sustainable enterprise. They are explained and illustrated briefly below. Please note that the examples described are for illustration and are neither exhaustive nor fixed.

\section{Control and Reduce the Bushmeat Trade.}

Action must be taken to gain control of the bushmeat trade -- to replace anarchy with organization. In turn the amount of trade in all wild game must be reduced. Particular attention should be directed at the critically threatened and protected animals. The African Primates Status Survey (14) suggests that among primates this begins with the drill (mandrillus leucophaeus), cercopithecus diana and sclateri, as well as bonobo, gorilla, and chimpanzee, but should also include primate communities that are under serious threat of annihilation. It is this author's opinion that we weigh genetic distinction too heavily in the classification of an animal's vulnerability. Isolated and specific groups and individuals may warrant protection, regardless of the numerousness of their assigned taxa.

Exemplary actions in this category are already being taken in some areas. In Cameroon there is now a ban on sale of the Chevrotine Cartridge -- the bullet sold specifically to fell great apes in one shot. Strict gun control and closed seasons are other solutions. Reducing the number of skilled gunmen is an option, by retraining bushmeat hunters into other trades. Hunters with positive conservation values may be employed as wildlife census takers, park guards, tour guides, bushmeat inspectors, and forest rangers. Resources for these efforts should come through partnerships with individuals and organizations in affluent countries wanting to help African counterparts develop their capacity to stop wildlife lawbreaking.

As stated earlier, much bushmeat control can be done through the timber industry. Logging companies should pay for proper governance of their company towns and territories by financing programs to ameliorate the bushmeat crisis. Some recommended actions are: a) provide domestic meat for workers and their families, b) conduct courses on wildlife laws and protection for all personnel in logging camps, with updates and indoctrinations for newcomers, c) create community/professional teams to interdict, arrest, reprimand, remediate, and monitor all persons on their concessions involved in unsafe, illegal, and unsustainable logging, hunting, marketing, housekeeping, etc. d) destroy bridges and logging roads once an area has been logged out, and support the monitoring of abandoned logging roads and camps, e) fund independent action-research efforts to assure that all logging and bushmeat hunting is sustainable.

\section{Develop and Provide Alternatives to Bushmeat}

If bushmeat use is to be reduced, there must be alternatives. Market preference is reflected in the public willingness to buy fresh game meat at 2-to-5 times the price of beef or chicken $(1,9,23)$. Governments should develop national Inter-Ministry programs linking Forestry, Wildlife Protection, Agriculture, and Finance Directorates to encourage and support the creation of eco-friendly community farms and meat markets to serve logging concessions and other areas where domestic food alternatives are needed most. International support should be provided to develop native wildlife ranching that can replace the bushmeat trade and become an export business. Studies are needed to determine the species which are preferred, plentiful, and can be profitably domesticated. This is another area in which hunters and traders involved in the bushmeat commerce can be reemployed, preferably in locations distant from forests, to reduce likelihood of return to hunting and to avoid encroachment of agribusiness into forested areas.

\section{Engender Wildlife Conservation Values}

Few people who have positive interaction with an orphaned great ape will want to keep eating them (16). Orphans are the best emissaries for their families in the forest. Bushmeat sanctuaries should be built near provincial capitals to be used as Wildlife Education and Research Centers by local schools and colleges. We have asked the American Zoo and Aquarium Association (AZA) to help form a consortium of wildlife related 
organizations that will partner with African NGOs to finance construction and management of such Centers. Local citizens can be employed to care for the orphans of the bushmeat trade. At these Centers teams of students, teachers and community leaders can be organized and deployed to generate public understanding and concern for wildlife and forests. Media and advertising campaigns, popular radio drama, and other publicity programs are needed to demonstrate how excessive reliance on bushmeat has adverse impact on vulnerable species, the wildlife heritage, and the economy in the long term.

\section{Establish National and Regional Bushmeat Programmes}

The above goals must be pursued as part of an integrated effort to standardize and implement national and regional bushmeat policy and practice. We are creating designs for such efforts based on organization development principles we have applied in other large community service systems (16). The details are too complex and preliminary to present here. In general we see a multi-level multi-community network that links all significant players in the bushmeat commerce through representative participation in national and regional Bushmeat Programme steering and planning committees. These committees support and coordinate the efforts of local bushmeat action teams and crisis intervention task forces co-developed by grass-roots community organizers and outside facilitators. The teams and task forces identify and intervene in problems and opportunities that relate to the overarching mission to protect the natural heritage and to the goals of controlling and reducing bushmeat trade, providing viable alternative foods, and engendering wildlife conservation values. All factions and stakeholders in the Programme hold one another accountable at regularly scheduled intergroup meetings and National Bushmeat Programme Congresses. As in most community-basedconservation efforts (24) those whose lives and livelihoods are most affected must have the strongest voice in decision making processes at all levels and locations.

\section{Promote Global Support for the Bushmeat Programmes}

The Cameroon Bushmeat Conference called for international partnerships to develop programs aimed at confronting the great ape bushmeat crisis. African national and regional bushmeat programmes will need technical and financial aid. Conservation NGOs must find ways to collaborate, rather than compete, if we are to have anything but small-scale short-term impact on the situation. This means we must open our books, both technical and financial, and share what we know and what we spend. From that position of trust, we can jointly organize our resources and direct our combined efforts with maximal effect.

But even with perfect collaboration, conservationists will not have the clout of bankers. A portion of our combined resource must go to influence the policy and action of major financiers and developers like the World Bank and the African Development Bank. These institutions must be convinced to make long-term conservation of natural and cultural heritage a driving force in their strategic and operational plans. They must accept that they are among the most powerful players in the region and the world, and thus are obligated to become responsible to the biosphere, and not merely to petty investors and stockholders. They must use their power to sustain social and ecological systems, not just corporate product and profit. Use their money and influence to help the people of Africa develop environmentally healthy food products, not build roads into forests that invite the anarchic rush of exploiters, eager to grab their gold and run.

Without a united conservation front affecting ecologically responsible finance and development, the great apes and all the other large fauna in the forests will be eaten to extinction. With them will go the indigenous forest people, who are the only humans with natural rights to be there. Next will go the timber, then what's left of oil and minerals. The people will be left with little more than debt and sand. We've seen this occur, time after time. It must not be allowed to happen again.

\section{What Can We Do Now?}

We recommend that all individuals and organizations involved with African primates consider making the bushmeat crisis a first priority issue on your conservation agendas. In particular, we urge you to join The Bushmeat Project's efforts to raise funds and share information. Send us articles and preprints describing bushmeat-related activities -- proposed, underway, and accomplished. We need to add these to the bushmeat bibliography posted on The Bushmeat Project Web Page Distribute resumes of people who you believe can contribute to this effort; in particular African nationals in the countries where great apes are hunted for meat. It is important to note that worthy persons in this arena may not be primatologists, or even professionals. We need to recognize and support the contributions of all disciplines, factions, and communities. Talk to us about joint fund-raising efforts, public education and media opportunities. Most important, talk with friends, colleagues, family about the bushmeat crisis. Then do something about it.

We want to help promote and support your work for the sake of the people and primates of Africa. - Anthony L. Rose, Director, The Biosynergy Institute / Bushmeat Project, P.O. Box 488, Hermosa Beach, CA USA. E-mail to bushmeat@biosynergy.org. Web-page: http://biosynergy.org/bushmeat/

\section{References}

1. Ammann, K. Slaughter of the apes. Talk at World Congress for Animals, Wash. DC, June, 1996

2. Ammann, K. Timber and bushmeat industries are linked throughout west/central Africa. Talk at Conference on The Impact of Forest Exploitation on 
Wildlife, Bertoua, Cameroon, April, 1996.

3. Ammann, K. Primates in peril, Outdoor Photographer, February, 1996.

4. Ammann, K. \& Pearce, J. Slaughter of the Apes: How the tropical timber industry is devouring Africa's great apes. World Society for the Protection of Animals, London, 1995.

5. Cameroon Ministry of Environment and Forests (MINEF). Proceedings and Recommendations of the Conference on The Impact of Forest Exploitation on Wildlife, Bertoua, Cameroon, April, 1996.

6. Eliot, J. Who will care for orphans of primates killed for food? National Geographics, National Geographic Society, Washington, February, 1996.

7. Fa, J. E. et al. Impact of market hunting on mammal species in Equatorial Guinea. Conservation Biology, 9, 1107-1115, October 1995.

8. Harcourt, A.H. \& Stewart, K.J. Is the gorilla a threatened species? How should we judge? Biological Conservation, $75,165-176,1996$

9. Hennessey, A. B. A Study of the Meat Trade in Ouesso, Republic of Congo. GTZ, Brazzaville, 1995.

10. Juste, J. et al. Market dynamics of bushmeat species in Equatorial Guinea. Journal of Applied Ecology, 32, 454467, 1995.

11. Merfield, F.G. \& Miller, H. Gorilla Hunter. Farrar, Straus, \& Cudahy, New York, 1956.

12. Mittermeier, R. A. Effects of hunting on rain forest primates. Pp. $109-146$ in Primate Conservation in the Tropical Rain Forest, Alan R. Liss, New York, 1987.

13. Oates, J.F. Habitat Alteration, hunting, and the conservation of folivorous primates in African forests. Australian Journal of Ecology, 21, 1-9, 1996.

14. Oates, J.F.. African Primates: Status Survey \& Action Plan (Revised), IUCN, Gland, 1996.

15. Redmond, I. Trade in Gorillas and Other Primates in the Peoples Republic of Congo, IPPL, 1989.

16. Rose, A. L. The importance of primates. Talk at Conference on The Impact of Forest Exploitation on Wildlife, Bertoua, Cameroon, April, 1996.17. Rose, A. L. Commercial exploitation of great ape bushmeat. Talk at Conference on The Impact of Forest Exploitation on Wildlife, Bertoua, Cameroon, April, 1996.

18. Rose, A.L. The African Forest Bushmeat Crisis. Report to Conservation Committee of the American Society of Primatologists, Madison, August, 1996.

19. Rose, A. L. \& Ammann, K. The African great ape bushmeat crisis. Talk and workshop at Congress of International Primatological Society / American Society of Primatologists, Madison, August, 1996.

20. Rose, A. L. The bushmeat crisis is conservation's first priority. Talk at IUCN Primate Conservation Roundtable Discussion on an Action Agenda, at Joint Congress of IPS/ASP, Madison, August, 1996.
21. Rose, A.L. et al. Developing Alternatives to Endangered Bushmeat: An International Programme of Community Based Partnerships, The Biosynergy Institute, October, 1996.

22. Stegner, W. The American West as Living Space. University of Michigan Press, Ann Arbor, 1987.

23. Steele, E. A. Study of the Value and Volume of Bushmeat Commerce in Gabon. WWF \& Gabon Ministry of Forests \& Environment, Libreville, 1994.

24. Western, D. et al. (eds.). Natural Connections: Perspectives in Community-Based Conservation. Island Press, Washington, 1994.

25. Wilkie, D. S. et al. Mechanized logging, market hunting, and a bank loan in Congo. Conservation Biology, 6, December 1992.

26. Yadji, B. A new dynamic for conservation of wildlife resources. Talk at Conference on The Impact of Forest Exploitation on Wildlife, Bertoua, Cameroon, April, 1996.

27. ZSE-TV / Incha Productions. Twilight of the Apes, Johannesburg, 1996

(Submitted September 21, 1996)

Copyright 1996, Anthony L. Rose, Hermosa Beach, California USA. 